\title{
COMPARATIVE STUDIES ON ANTIDIABETIC, ANALGESIC, AND CYTOTOXIC EFFECT OF ETHANOLIC EXTRACTS OF AMARANTHUS GANGETICUS L. AND ALTERNANTHERA SESSILIS L.
}

\author{
MD. MOHAIMENUL*, KATHY DUTTA, NOWRIN FERDIOUSI, DEBENDRA NATH ROY
}

Department of Pharmacy, Jashore University of Science and Technology, Jashore, Bangladesh. Email: mohaimenulpharjust@gmail.com Received: 26 July 2020, Revised and Accepted: 10 September 2020

\section{ABSTRACT}

Objective: The present study was designed to evaluate and compare antidiabetic, analgesic, and cytotoxic properties of Lal shak (Amaranthus gangeticus L.) and Chanchi shak (Alternanthera sessilis L.). We carried out this work to explore the medicinal uses of very common and cheap leafy plant vegetables among the people of all classes.

Methods: The antidiabetic activity was evaluated and compared by studying the effect of ethanolic extract of A. gangeticus (EEAG) and ethanolic extract of $A$. sessilis (EEAS) against blood glucose level of alloxan-induced diabetic mice in every $6 \mathrm{~h}$ for $24 \mathrm{~h}$. To evaluate and compare analgesic and cytotoxic activity, different tests such as acetic acid-induced writhing test, hot plate test, and brine shrimp lethality bioassay test had been performed.

Results: The mice were treated with both plants extract at a dose of $200 \mathrm{mg} / \mathrm{kg}$ body weight in case of antidiabetic activity test. Blood glucose level was examined and found that there was a significant reduction of blood glucose level with EEAG $(p<0.05)$ and EEAS $(p<0.001)$ in comparison with their respective diabetic control group. Although both plant extracts reduced the blood glucose level, the glucose reducing effect was higher in EEAS. Both the plants showed significant $(\mathrm{p}<0.05)$ peripheral analgesic activity in treated mice but no significant central analgesic activity. EEAG showed higher peripheral analgesic activity than EEAS. In brine shrimp lethality bioassay, both the plants showed higher $\mathrm{LC}_{50}$ value thus cytotoxicity occurs at very higher dose and safe to administer.

Conclusion: In this study, both the plants showed sufficient antidiabetic property and higher $\mathrm{LC}_{50}$ value, thus administration of leafy vegetable Lal shak and Chanchi shak may be useful for diabetic people. Chanchi shak may be more helpful for diabetic people than Lal shak.

Keywords: Amaranthus gangeticus L., Alternanthera sessilis L., Antidiabetic, Analgesic, Cytotoxic.

(C) 2020 The Authors. Published by Innovare Academic Sciences Pvt Ltd. This is an open access article under the CC BY license (http://creativecommons. org/licenses/by/4. 0/) DOI: http://dx.doi.org/10.22159/ajpcr.2020.v13i11.39232

\section{INTRODUCTION}

Plants have played a significant role in maintaining human health and improving the quality of human life [1]. In traditional medicine, there are numerous medicinal plants that have the potentiality to treat many diseases and disorders. Leafy vegetables are considered essential for well-balanced diets since they supply vitamins, minerals, dietary fiber, and phytochemicals. Having unique combination and amount of these phytonutraceuticals, each vegetable distinguishes from each other within their own group. To improve gastrointestinal health, good vision, and reduced risk of heart disease, stroke, chronic diseases such as diabetes, and some forms of cancer, vegetables plays strong rule [2]. A vast majority of the population, particularly those living in rural areas, depends largely on medicinal plants and vegetable diet for the treatment of disease.

Amaranthus gangeticus L. belongs to the family Amaranthaceae with approximately 60 species that are acknowledged [3]. A. gangeticus $\mathrm{L}$. originates from tropical Asia. In South and Southeast Asia (SEA), it is one of the major leaf vegetables and the most important Amaranthus species. A. gangeticus L. has mild spinach like flavor, high nutritive value, ability to grow in hot weather, and lower cost that made it a very popular vegetable. This plant is well known for its purple betalain pigments, such as amaranthine and isoamaranthine [4]. Goan/Indian folklore describes that the plant is a good liver tonic and therefore recommended as a vegetable for diabetic and anemic patients.

Alternanthera sessilis (L.) R.Brex DC. (Family: Amaranthaceae) is an annual, many branched herb. It can be erect or prostrate, rooting at the nodes, or may occasionally be a floating or emergent aquatic. The stems are greenish, pink to purplish, ribbed, up to $1 \mathrm{~m}$, mostly glabrous except for tufts of white hairs in the branch and leaf axils. The species occurs in tropical and subtropical regions. It is found all over the most of Africa, south of the Sahara and Egypt, throughout the Middle East, east through the Indian subcontinent, most Indian Ocean island groups. The leaves are used in eye diseases, cuts, wounds, and antidote to snake bite; skin diseases [5]. It is also reported about the wound healing property of $A$. sessilis L. [6]. The plants aerial parts also have shown a hepatoprotective activity [7].

Diabetes mellitus is a chronic and endocrine disorder caused by inherited and/or acquired efficiency in the production of insulin by the pancreas or by the inability of the insulin production. Type I diabetes (insulin dependent) is a condition characterized by insulin insufficiency because of lack of functional beta cells. Type II diabetes mellitus is a heterogeneous disorder characterized by a progressive decline in insulin action followed by the pancreatic beta cell dysfunction [8]. Complications such as renal failure, coronary artery disorder, cerebrovascular disease, neurological complications, blindness, dyslipidemia, obesity, limb amputation and failure of various organs, and eventually premature death are related with chronic hyperglycemia [9].

Pain and inflammation are reactions against detrimental stimuli, infection, trauma, or injury in the living tissues [10]. In most cases, pain and inflammation are treated by nonsteroidal anti-inflammatory drugs (NSAIDs). According to various medical literatures, various adverse reactions are known to be associated with the NSAIDs, thereby limiting the widespread use of these agents. Development of newer antiinflammatory constituents possessing fewer side effects still remains a challenge to the scientific community.

The brine shrimp lethality assay is a general bioassay that seems to be capable of identifying a wide spectrum of bioactivity present in crude 
extracts. The commercial availability of economical brine shrimp eggs, the low cost, the safety, and ease of performing the assay, as well as no special technology requirement make this a very helpful tool for the phytochemistry laboratory [11]. The method is attractive because it is very simple, inexpensive and low toxin amounts are sufficient to perform the test in the small scale.

In this study, an attempt has been made to evaluate and compare the antidiabetic, analgesic, and cytotoxic effects of ethanolic extract of A. gangeticus (EEAG) and ethanolic extract of $A$. sessilis (EEAS) with a view toward elucidation and comparison of the probable claimed effects using various experimental models.

\section{METHODS}

\section{Drugs and chemicals}

Diclofenac sodium and metformin were procured from Square Pharmaceuticals Ltd., Bangladesh. Alloxan and vincristine sulfate were supplied by the Department of Pharmacy, Jashore University of Science and Technology (JUST) laboratory. All solvents and reagents used were of analytical grade and solvents obtained from Merck, Germany.

\section{Plant material}

The Lal shak (A. gangeticus L.) and Chanchi shak (A. sessilis L.) were selected for this investigation. These were collected and identified from various areas of Jashore $\left(23.1634^{\circ} \mathrm{N}, 89.2182^{\circ} \mathrm{E}\right)$ and Satkhira $\left(22.3155^{\circ} \mathrm{N}, 89.1115^{\circ} \mathrm{E}\right)$, Bangladesh, during the month of October 2017

\section{Preparation of plant extracts}

The whole plant of A. gangeticus L. and aerial part of A. sessilis L. were thoroughly washed with fresh water to remove all contaminants and dried under shade at room temperature for a period of 9 days. Coarse powder of the materials was produced by grinding the materials with the help of a grinder. The coarsely powdered materials were weighted and about $500 \mathrm{mg}$ of both powdered materials were macerated with ethanol (1:3) at room temperature for a period of 10 days with occasional shaking and stirring. The whole mixture was filtered through cotton and then Whatman No.1 filter papers. The solvent of the filtrate thus obtained was evaporated by rotary evaporator (Witeg, Germany, Model No: 2600000) to get the final extract (viscous mass). Then, the extract was stored in refrigerator $\left(4^{\circ} \mathrm{C}\right)$ for further use.

\section{Experimental animals}

A 4-5-week-old aged female Swiss albino mice of body weight 20-30 g (procured from the Department of Pharmacy, Jahangirnagar University, Savar, Dhaka, Bangladesh) were used to run the antidiabetic and analgesic experiments. Before initiating the experiments, the animals were kept under standard environmental conditions, maintained $55-65 \%$ relative humidity, and exposed to alternative $12: 12 \mathrm{~h}$ light and dark cycle at an ambient temperature of $26 \pm 2^{\circ} \mathrm{C}$. Proper arrangement of foods and water ad libitum was ensured. Before the experiment, mice were habituated for 7 days in our laboratory environment and ensured the constant environmental and adequate nutritional conditions throughout the period of the experiment. Artemia salina Leach (brine eggs) was used for brine shrimp cytotoxicity test. This study was approved by ethical research committee of JUST, Jashore-7408, Bangladesh. The ethical approval number is ERC/FBS/JUST/2018-19.

\section{Antidiabetic activity test}

\section{Experimental induction of diabetes}

Group animals were allowed to fast for $12 \mathrm{~h}$ and rendered diabetic by injection intraperitoneally with a freshly prepared solution of alloxan monohydrate (180 mg/kg body) [12] in normal saline after baseline glucose estimation was done. After alloxan induction, hypoglycemia may develop. To overcome alloxan-induced hypoglycemia, the alloxantreated mice were allowed to food overnight. After $48 \mathrm{~h}$, blood glucose concentration was measured using Rapid View ${ }^{\mathrm{TM}}$ blood glucose test meter using blood sample from the tail vein of the mice. The mice having blood glucose level above $11.1 \mathrm{mmol} / \mathrm{l}$ were considered as diabetic mice and selected for the study.

\section{Experimental Design}

Seven groups of mice, five in each received the following treatment schedule.

Group I: Normal control (saline $10 \mathrm{ml} / \mathrm{kg}$ p.o.)

Group II: Alloxan-treated control (180 mg/kg.ip)

Group III: Alloxan (180 mg/kg.ip) + A. gangeticus L. plants extract (200 mg/kg, p.o)

Group IV: Alloxan (180 mg/kg.ip) + A. sessilis L. plants extract (200mg/kg, p.o),

Group V: Alloxan (180 mg/kg.ip) + Standard drug, metformin (150 mg/kg, p.o)

Group VI: Normal A. gangeticus L. plants extract (200 mg/kg, p.o)

Group VII: Normal A. sessilis L. plants extract (200 mg/kg, p.o).

\section{Final observation}

Both the plant extracts $(200 \mathrm{mg} / \mathrm{kg}$ ) and standard drug metformin $(150 \mathrm{mg} / \mathrm{kg}$ ) were given orally according to experimental design and blood glucose concentration was measured using Rapid View ${ }^{\mathrm{TM}}$ blood glucose test meter using blood sample from the tail vein of the mice in every $6 \mathrm{~h}$ for $24 \mathrm{~h}$.

\section{Analgesic activity}

Acetic acid-induced writhing test in mice

The test was conducted by modified method of Koster et al. [13].

Six groups of mice, five in each received the following treatment schedule.

Group I: Control. (10 ml/kg distilled water. p.o.)

Group II: A. gangeticus L. plants extract (200 mg/kg. p.o.)

Group III: A. gangeticus L. plants extract ( $400 \mathrm{mg} / \mathrm{kg}$, p.o)

Group IV: A. sessilis L. plants extract (200 mg/kg, p.o)

Group V: A. sessilis L. plants extract (400 mg/kg, p.o)

Group VI: Diclofenac Na (100 mg/kg, p.o).

After 45 min of respective treatment, each mouse was injected intraperitoneally with $0.7 \%(\mathrm{v} / \mathrm{v})$ acetic acid at a dose of $10 \mathrm{ml} / \mathrm{kg}$ body weight. Acetic acid is induced to provoke writhing activity. The writhing activity comprised constriction of the abdominal muscles together with a stretching of the hind limbs. The number of writhing responses of each mouse was counted for a 5-min period, which began 15 min late of acetic acid administration.

To determine the percentage of inhibition of writhing, the following formula was used.

$$
\begin{aligned}
& \text { Mean no of writhes(control) - } \\
& \% \text { Inhibition }=\frac{\text { mean no of writhes(test) }}{\text { Mean no of writhes }(\text { control })} \times 100
\end{aligned}
$$

\section{Hot plate test}

Hot plate test was performed according to the method of Turner [14]. The method was used to evaluate the central mechanism of analgesic activity [15]. At first, mice were screened for this test by inserting them on a hot plate individually that was kept at $55 \pm 1^{\circ} \mathrm{C}$. The mice that showing initial reaction time (difference of time between the placement of mice on hot plate and their responses to occur) of $15 \mathrm{~s}$ or less were selected for this study. During screening, the paw of mice may be damaged. A cutoff point of $15 \mathrm{~s}$ was used to overcome the problem of paw damage. Tramadol (10 mg/kg) was used as the standard drug. The mice were fasted for $16 \mathrm{~h}$ with water ad libitum. Thirty min before the treatment of each group, the response latencies of mice were recorded by placing them on hot plate after the observations of some parameters such as removal, jumping, or licking of the paws. The response latencies were also counted after 30,60, 120, and 180 min of the respective treatment of each group. 
Table 1: Effects of A. gangeticus L. and A. sessilis L. extract on blood glucose level in alloxan-induced diabetic mice

\begin{tabular}{|c|c|c|c|c|c|c|c|}
\hline \multirow[t]{3}{*}{ Time in hour } & \multicolumn{7}{|c|}{ Blood glucose level in $\mathrm{mmol} / \mathrm{L}$} \\
\hline & \multirow{2}{*}{$\begin{array}{l}\text { Non-diabetic mice } \\
\text { Normal control }\end{array}$} & \multicolumn{4}{|c|}{ Diabetic mice } & \multicolumn{2}{|c|}{ Non-diabetic mice } \\
\hline & & $\begin{array}{l}\text { Diabetic } \\
\text { control }\end{array}$ & $\begin{array}{l}\text { Alloxan } \\
\text { +Metformin }\end{array}$ & $\begin{array}{l}\text { Alloxan+ } \\
\text { EEAG }\end{array}$ & Alloxan+ EEAS & $\begin{array}{l}\text { Non- } \\
\text { diabetic+EEAG }\end{array}$ & $\begin{array}{l}\text { Non- } \\
\text { diabetic+EEAS }\end{array}$ \\
\hline $0 \mathrm{~h}$ & $6.28 \pm 0.65$ & $19.95 \pm 1.61$ & $24.66 \pm 2.98$ & $22.17 \pm 2.70$ & $18.12 \pm 2.44$ & $5.18 \pm 0.88$ & $8.15 \pm 0.93$ \\
\hline $6 \mathrm{~h}$ & $4.94 \pm 0.45$ & $20.0 \pm 1.66$ & $11.42 \pm 2.51^{*}$ & $15.62 \pm 3.66$ & $11.47 \pm 1.74^{*}$ & $3.32 \pm 0.41^{* * *}$ & $7.62 \pm 4.02 *$ \\
\hline $12 \mathrm{~h}$ & $4.88 \pm 0.32$ & $19.92 \pm 1.055$ & $17.94 \pm 4.54$ & $23.70 \pm 3.84$ & $16.47 \pm 3.03$ & $4.48 \pm 0.42^{* *}$ & $7.15 \pm 2.36^{*}$ \\
\hline $18 \mathrm{~h}$ & $4.74 \pm 0.12$ & $20.25 \pm 1.55$ & $11.62 \pm 3.92^{*}$ & $11.80 \pm 2.15^{*}$ & $10.27 \pm 3.43^{*}$ & $4.46 \pm 0.43^{* * *}$ & $5.12 \pm 1.84^{* *}$ \\
\hline $24 \mathrm{~h}$ & $3.76 \pm 0.48$ & $18.95 \pm 1.44$ & $8.30 \pm 1.67^{* * *}$ & $14.35 \pm 2.40$ & $6.87 \pm 1.07^{* * *}$ & $3.37 \pm 0.58^{* * *}$ & $6.17 \pm 1.55^{* * *}$ \\
\hline
\end{tabular}

The blood glucose level was expressed as mean ( \pm S.E.M.) values. Level of significance $* * *=p<0.001, * *=p<0.01, *=p<0.05$ compared to diabetic control. (ANOVA followed by Dunnett's t-test). EEAG: Ethanolic extract of A. gangeticus L., EEAS: Ethanolic extract of A. sessilis L. A. gangeticus: Amaranthus gangeticus, A. sessilis: Alternanthera sessilis

Table 2: Effects of $A$. gangeticus and $A$. sessilis on acetic acid-induced mice

\begin{tabular}{llll}
\hline Group & Dose & MW \pm SEM & \% inhibition \\
\hline Control & $10 \mathrm{ml} / \mathrm{kg}$ & $24.20 \pm 2.00998$ & 0 \\
Standard & $100 \mathrm{mg} / \mathrm{kg}$ & $13.20 \pm 2.53772^{* *}$ & 45.45 \\
EEAG-200 & $200 \mathrm{mg} / \mathrm{kg}$ & $17 \pm 1.30384$ & 29.75 \\
EEAG-400 & $400 \mathrm{mg} / \mathrm{kg}$ & $13.80 \pm 1.11355^{*}$ & 42.98 \\
EEAS-200 & $200 \mathrm{mg} / \mathrm{kg}$ & $15.40 \pm 4.10609^{*}$ & 36.36 \\
EEAS-400 & $400 \mathrm{mg} / \mathrm{kg}$ & $18 \pm 2.73861$ & 25.62
\end{tabular}

The no. of writhing was expressed as mean ( \pm S.E.M.) values. Level of significance $^{* * *}=\mathrm{p}<0.001,{ }^{* *}=\mathrm{p}<0.01,{ }^{*}=\mathrm{p}<0.05$ compared to control. (ANOVA followed by Dunnett's t-test). [MW: Mean writhing, SEM: Standard error mean, EEAG: Ethanolic extract of A. gangeticus L., EEAS: Ethanolic extract of A. sessilis L.]. A. gangeticus: Amaranthus gangeticus, A. sessilis: Alternanthera sessilis

\section{Experimental design}

Six groups of mice, five in each received the following treatment schedule.

Group I: Control (10 ml $/ \mathrm{kg}$ distilled water. p.o.)

Group II: A. gangeticus L. plants extract $(200 \mathrm{mg} / \mathrm{kg}$. p.o.)

Group III: A. gangeticus L. plants extract $(400 \mathrm{mg} / \mathrm{kg}, \mathrm{p} . \mathrm{o})$

Group IV: A. sessilis L. plants extract $(200 \mathrm{mg} / \mathrm{kg}, \mathrm{p.o})$

Group V: A. sessilis L. plants extract ( $400 \mathrm{mg} / \mathrm{kg}$, p.o)

Group VI: Tramadol (10 mg/kg, p.o).

\section{Cytotoxic activity}

Brine shrimp lethality bioassay

The brine shrimp lethality bioassay was carried out on EEAG and EEAS using the standard procedure of Meyer et al. [16]. To prepare simulated sea water $(3.8 \% \mathrm{NaCl}$ in water), $38 \mathrm{~g} \mathrm{NaCl}$ was dissolved in $1 \mathrm{~L}$ of distilled water. A conical-shaped vessel containing previously prepared $1 \mathrm{~L}$ artificial seawater at $25-30^{\circ} \mathrm{C}$ temperature with a constant oxygen supply was used to hatching brine shrimp (A. salina) eggs. A. salina eggs took about 24-48 $\mathrm{h}$ to be hatched. Using a pipette, the larvae (nauplii) were collected. Dimethyl sulfoxide (DMSO, 1\%) was used to dissolve the sample extract and the extract was then transferred into test tubes following the method of serial dilution in such way that each test tube contained $10 \mathrm{ml}$ of artificial sea water having four different sample concentrations 800, 400, 200, and $100 \mu \mathrm{g} / \mathrm{ml}$. Ten nauplii were placed in each test tube. DMSO (1\%) was added to four test tubes. Vincristine sulfate was used as the positive control following the method of serial dilution in such way that each test tube contained $10 \mathrm{ml}$ of artificial sea water having four different vincristine sulfate concentrations at 10,5 , 1 , and $0.5 \mu \mathrm{g} / \mathrm{ml}$. Again, ten nauplii were dropped in each test tube of positive control group. A negative control group was also tested having 10 nauplii in $10 \mathrm{ml}$ sea water containing DMSO (1\%). Following the period of $24 \mathrm{~h}$ at room temperature, the number of viable nauplii was counted.

\section{Statistical analysis}

The analysis was performed using SPSS statistical package for WINDOWS (version 23.0; SPSS Inc., Chicago). For antidiabetic and analgesic tests, the results of the study are expressed as mean \pm S.E.M and statistical significance between control and treated groups was evaluated by one-way analysis of variance (ANOVA) followed by Dunnett's t-test and levels at $\mathrm{p}<0.05$ were considered significant, $\mathrm{p}<0.01$ considered highly significant, and $\mathrm{p}<0.001$ considered very highly significant compared to control. For brine shrimp lethality bioassay, $\mathrm{LC}_{50}$ values were determined, based on the percentage mortality using Microsoft Office Excel scatter analysis.

\section{RESULTS}

\section{Antidiabetic activity test}

The result obtained from antidiabetic activity test is described in Table 1. Both the plant extracts were given at a dose of $200 \mathrm{mg} / \mathrm{kg}$ body weight and standard drug metformin was given at a dose of $150 \mathrm{mg} / \mathrm{kg}$ body weight. The effect of EEAG and EEAS on the blood glucose level of experimental mice was determined at every $6 \mathrm{~h}$ for $24 \mathrm{~h}$. During $6 \mathrm{~h}$ observation, EEAS and metformin showed significant $(\mathrm{p}<0.05)$ reduction of blood glucose level with a mean value of $11.47 \pm 1.74 * \mathrm{mmol} / \mathrm{L}$ and $11.42 \pm 2.51 * \mathrm{mmol} / \mathrm{L}$, respectively. At $18 \mathrm{~h}$, EEAG, EEAS, and metformin also showed significant $(\mathrm{p}<0.05)$ reduction of blood glucose level with a mean value of $11.80 \pm 2.15^{*} \mathrm{mmol} / \mathrm{L}, 10.27 \pm 3.43^{*} \mathrm{mmol} / \mathrm{L}$, and $11.62 \pm 3.92 * \mathrm{mmol} / \mathrm{L}$, respectively. At $24 \mathrm{~h}$, EEAS and metformin showed very highly significant $(\mathrm{p}<0.001)$ reduction of blood glucose level with a mean value of $6.87 \pm 1.07^{* * *} \mathrm{mmol} / \mathrm{L}$ and $8.30 \pm 1.67^{* * *} \mathrm{mmol} / \mathrm{L}$, respectively. Thus, EEAS has more blood glucose reduction ability than EEAG.

\section{Analgesic activity}

Acetic acid-induced writhing test in mice

The results of acetic acid-induced writhing test are displayed in Table 2 . EEAG at a dose of $400 \mathrm{mg} / \mathrm{kg}$ and EEAS at a dose of $200 \mathrm{mg} / \mathrm{kg}$ body weight showed significant $(\mathrm{p}<0.05)$ analgesic effect with a mean value of $13.80 \pm 1.11355^{*}$ and $15.40 \pm 4.10609^{*}$, respectively, with percentage of inhibition 42.98 and 36.36, respectively. Diclofenac sodium $(100 \mathrm{mg} / \mathrm{kg})$ used as standard drug which showed highly significant $(\mathrm{p}<0.01)$ analgesic effect with mean value of $13.20 \pm 2.53772^{* *}$ and $45.45 \%$ inhibition.

\section{Hot plate test}

The result of hot plate test is summarized in Table 3. This method is used to evaluate the central mechanism of analgesic activity. In this study, both the plant extracts were given 200 and $400 \mathrm{mg} / \mathrm{kg}$ body weight and standard tramadol was given as $10 \mathrm{mg} / \mathrm{kg}$ body weight orally. Both the plant extracts showed no significant analgesic effect.

\section{Cytotoxic activity}

Brine shrimp lethality bioassay

Brine shrimp lethality activity of EEAG and EEAS is shown in Table 4. The lethality concentration $\left(\mathrm{LC}_{50}\right.$ ) of EEAG is $1213 \mu \mathrm{g} / \mathrm{ml}$ and EEAS is $1364 \mu \mathrm{g} / \mathrm{ml}$ making those classified as non-toxic according to Meyer's toxicity index for BSLA [16]. None of the extract managed to achieve 
Table 3: Effects of A. gangeticus L. and A. sessilis L. in hot plate test

\begin{tabular}{|c|c|c|c|c|c|c|}
\hline \multirow[t]{2}{*}{ Group } & \multirow[t]{2}{*}{ Dose } & \multicolumn{5}{|c|}{ Response latency period(s) } \\
\hline & & 0 min & $30 \mathrm{~min}$ & $60 \mathrm{~min}$ & $120 \mathrm{~min}$ & $180 \mathrm{~min}$ \\
\hline Control & $10 \mathrm{ml} / \mathrm{kg}$ & $6.8920 \pm 2.07599$ & $6.1720 \pm 1.03892$ & $7.9680 \pm .29937$ & $5.0020 \pm .61553$ & $4.8000 \pm .94814$ \\
\hline Standard & $10 \mathrm{mg} / \mathrm{kg}$ & $4 \pm 0.71^{*}$ & $3.41 \pm 0.40^{*}$ & $3.6 \pm 0.73^{*}$ & $3.52 \pm 0.5^{*}$ & $1.8 \pm 0.49^{* *}$ \\
\hline EEAG200 & $200 \mathrm{mg} / \mathrm{kg}$ & $6.2720 \pm 1.20011$ & $5.7540 \pm 1.14492$ & $3.2460 \pm 0.33992$ & $4.3800 \pm 0.81997$ & $4.4060 \pm 0.77272$ \\
\hline EEAG400 & $400 \mathrm{mg} / \mathrm{kg}$ & $5.9780 \pm 1.41151$ & $5.0220 \pm .45817$ & $5.3260 \pm 0.93404$ & $4.2880 \pm .96103$ & $4.9440 \pm 0.57867$ \\
\hline EEAS200 & $200 \mathrm{mg} / \mathrm{kg}$ & $8.7660 \pm 1.50797$ & $6.0600 \pm 1.16816$ & $6.2400 \pm 1.29631$ & $3.0080 \pm 0.44125$ & $5.1340 \pm 0.80834$ \\
\hline EEAS400 & $400 \mathrm{mg} / \mathrm{kg}$ & $5.3680 \pm 0.46645$ & $8.3760 \pm 1.12082$ & $5.0600 \pm .41662$ & $3.6940 \pm 0.75662$ & $5.2125 \pm 0.53266$ \\
\hline
\end{tabular}

The response latency period was expressed as mean ( \pm S.E.M.) values. Level of significance $* * *=p<0.001, * *=p<0.01, *=p<0.05$ compared to control. (ANOVA followed by Dunnett's t-test). [MW: Mean writhing, SEM: Standard error mean, EEAG: Ethanolic extract of $A$. gangeticus L., EEAS: Ethanolic extract of $A$. sessilis L.]. A. gangeticus: Amaranthus gangeticus, A. sessilis: Alternanthera sessilis

Table 4: $\mathrm{LC}_{50}$ of the A. gangeticus $\mathrm{L}$. and $A$. sessilis $\mathrm{L}$. in brine shrimp lethality bioassay

\begin{tabular}{|c|c|c|c|c|}
\hline $\begin{array}{l}\text { Test } \\
\text { sample }\end{array}$ & $\begin{array}{l}\text { Concentration } \\
(\mu \mathrm{g} / \mathrm{ml})\end{array}$ & $\%$ mortality & $\begin{array}{l}\mathrm{LC}_{50} \\
(\mu \mathrm{g} / \mathrm{ml})\end{array}$ & $\begin{array}{l}\text { Toxicity c } \\
\text { lass }\end{array}$ \\
\hline \multirow[t]{4}{*}{ EEAG } & 100 & 10 & \multirow{4}{*}{1213} & \multirow[t]{4}{*}{ Non-toxic } \\
\hline & 200 & 30 & & \\
\hline & 400 & 30 & & \\
\hline & 800 & 40 & & \\
\hline \multirow[t]{4}{*}{ EEAS } & 100 & 10 & \multirow[t]{4}{*}{1364} & \multirow[t]{4}{*}{ Non-toxic } \\
\hline & 200 & 20 & & \\
\hline & 400 & 30 & & \\
\hline & 800 & 30 & & \\
\hline \multirow[t]{4}{*}{ VS } & 0.5 & 40 & \multirow[t]{4}{*}{0.93} & \multirow[t]{4}{*}{ Toxic } \\
\hline & 1 & 50 & & \\
\hline & 5 & 90 & & \\
\hline & 10 & 100 & & \\
\hline
\end{tabular}

EEAG: Ethanolic extract of A. gangeticus L.; EEAS: Ethanolic extract of A. sessilis L.; VS: Vincristine sulfate. A. gangeticus: Amaranthus gangeticus, A. sessilis: Alternanthera sessilis

$100 \%$ lethality even at the highest concentration $1000 \mu \mathrm{g} / \mathrm{ml}$. Standard drug vincristine sulfate had a $\mathrm{LC}_{50}$ value of $0.93 \mu \mathrm{g} / \mathrm{ml}$.

\section{DISCUSSION}

Diabetes mellitus is a chronic, endocrine disorder characterized by inability of cell to utilize insulin or by the ineffectiveness of the insulin production by pancreas. The International Diabetes Federation SEA Region, which composes of the countries of India, Sri Lanka, Bangladesh, Bhutan, Mauritius, and Maldives, has a high prevalence of diabetes. It has been reported that there were more than 72 million adults with diabetes in 2013, a number that is expected to exceed 123 million by 2035. Nearly $95 \%$ of people of the total diabetic patients have type 2 diabetes (T2DM) [17]. Moreover, another 24.3 million people have impaired glucose tolerance [18]. Both rural and urban population have reported increases in the number of diabetic people [19]. In a cross-sectional survey of 402 people among the urban middle class in Bangladesh, it has been reported that 35\% had T2DM and $45 \%$ had metabolic syndrome [20]. Diabetes can progress to other disorders such as cardiovascular, kidney, and eye disorders. In fact, a high prevalence of chronic kidney disease has been seen following a community survey of urban people of Bangladesh, which has been correlated with insulin resistance [21].

We evaluate and compare the antidiabetic effect of EEAG and EEAS. In this study, we found that standard drug metformin reduced the blood glucose level from 24.66 to $8.30 \mathrm{mmol} / \mathrm{L}( \pm \mathrm{SEM}$ ) within $0-24 \mathrm{~h}$. On the other hand, EEAG decreased blood glucose level from 22.17 to $14.35 \mathrm{mmol} / \mathrm{L}$ $( \pm$ SEM $)$ in alloxan-induced diabetic mice within $0-24 \mathrm{~h}$ and EEAS decreased blood glucose level from 18.12 to $6.87 \mathrm{mmol} / \mathrm{L}$ ( \pm SEM) in alloxan-induced diabetic mice within $0-24 \mathrm{~h}$ which indicate that EEAS has higher hypoglycemic effect than EEAG (Table 1).
Acetic acid-induced writhing is a standard test for pain sensitivity to non-opiate analgesics. In writhing response experiments, the analgesic mechanism has been characterized as the release of different endogenous noxious mediators such as bradykinin, serotonin, histamine, and substance $P[22,23]$. In this study, EEAG at a dose $400 \mathrm{mg} / \mathrm{kg}$ showed significant reduction of number of writhing with a mean value $13.80 \pm 1.11355^{*}$ and percentage of inhibition showed $42.98 \%$. EEAS at a dose $200 \mathrm{mg} / \mathrm{kg}$ also showed significant reduction of number of writhing with a mean value $15.40 \pm 4.10609^{*}$ and percentage of inhibition showed $36.36 \%$. EEAG showed higher peripheral analgesic activity at higher dose and EEAS showed higher peripheral analgesic activity at lower dose. EEAG showed higher percentage of inhibition of writhing than EEAS (Table 2). Hot plate test is used to evaluate the central analgesic activity [13]. EEAG and EEAS have not showed any significant reduction of latency period in hot plate test (Table 3). Thus, it might be concluded that EEAG and EEAS have no central analgesic activity.

The rapid and simple brine shrimp lethality assay is considered as an economical bioassay for testing plant extracts bioactivity which in most cases associates considerably well with cytotoxic and anti-tumor properties [24]. The $\mathrm{LC}_{50}$ value over $1000 \mu \mathrm{g} / \mathrm{ml}$ is considered as toxic while the $\mathrm{LC}_{50}$ value below $1000 \mu \mathrm{g} / \mathrm{ml}$ is considered as non-toxic [16]. The $\mathrm{LC}_{50}$ value showed by both the plant extracts prove that both the extracts are non-toxic thus safe to administer (Table 4).

\section{CONCLUSION}

It can be concluded that both EEAG and EEAS showed its effectiveness as an antidiabetic and peripheral analgesic agent and EEAS has higher antidiabetic activity and EEAG has higher peripheral analgesic activity with high $\mathrm{LC}_{50}$ value in brine shrimp assay indicating that it is safe to administer for people. We hope that further detailed investigation is underway to determine the exact bioactive phytoconstituents that are responsible for those activities of those plants. Moreover, it could be a potential source for novel "lead" discovery for antidiabetic and analgesic drug development.

\section{ACKNOWLEDGMENT}

I would like to thank Md. Abdullah Aziz, Assistant Professor, Department of Pharmacy, JUST, Jashore, Bangladesh, for giving valuable ideas during experimental periods. Authors are also grateful to the authority of the Department of Pharmacy, JUST, for giving the opportunity to conduct such valuable experiments and providing necessary chemicals, instruments, and utility support.

\section{AUTHORS' CONTRIBUTIONS}

Md. Mohaimenul carried out the collection of plant, extraction process. Md. Mohaimenul, Kathy Dutta, and Nowrin Ferdiousi conducted the research work, conception and design of the study, statistical analysis and interpretation of data, and wrote the manuscript. Debendra Nath Roy supervised Md. Mohaimenul to conduct all the process. All authors read and approved the final manuscript. 


\section{AUTHORS' FUNDING}

There had not any funding supports for carrying this research. The total cost of completing the research work was carried by authors own finance.

\section{CONFLICTS OF INTEREST}

No conflicts of interest.

\section{REFERENCES}

1. Tamilselvan N, Thirumalai T, Elumalai EK, Balaji R, David E. Pharmacognosy of Coccinia grandis: A review. Asi Pac J Trop Biomed 2011:1:S299-302.

2. Dias JS. Nutritional quality and health benefits of vegetables: A review. Food Nutr Sci 2012;3:1354-74.

3. Jerz G, Arrey TN, Wray V, Du Q, Winterhalter P. Structural characterization of 132-hydroxy-(132-S)-phaeophytin-a from leaves and stems of Amaranthus tricolor isolated by high-speed countercurrent chromatography. Innovative Food Sci Emerg Technol 2007;8:413-8.

4. Anjali K, Joshi A, Maloo SR, Sharma R. Assessment of the morphological and molecular diversity in Amaranthus spp. Afr J Agric Res 2013;8:2307-11.

5. Gupta RS, Sharma R. A Review on Medicinal Plants Exhibiting Antifertility Activity in Males. New Delhi: ICMR; 2004. p. 151-7.

6. Jalalpure SS, Agrawal N, Patil MB, Chimkode R, Tripathi A. Antimicrobial and wound healing activities of leaves of Alternanthera sessilis Linn. Int J Green Pharm 2008;2:141-4.

7. Kumar A, Das M, Mohanraj P, Das A. Antimicrobial activity study of ethanolic extract of Alternanthera sessilis Linn. Aerial parts. J Appl Pharm Res 2014;2:1-4.

8. Srinivasan K, Viswanad B, Asrat L, Kaul CL, Ramarao P. Combination of high-fat diet-fed and low-dose streptozotocin-treated rat: A model for Type 2 diabetes and pharmacological screening. Pharmacol Res 2005;52:313-20.

9. Lanjhiyana S, Garabadu D, Ahirwar D, Bigoniya P. Antidiabetic activity of methanolic extract of stem bark of Elaeodendron glaucum Pers. In alloxanized rat model. Adv Appl Sci Res 2011;2:47-62.

10. Naher S, Aziz MA, Akter MI, Rahman SM, Sajon SR. Analgesic, anti-inflammatory and anti-pyretic activities of methanolic extract of
Cordyline fruticosa (L.) A. Chev Leaves J Res Pharm 2019;23:198-207.

11. Khalighi-Sigaroodi F, Ahvazi M, Hadjiakhoondi A, Taghizadeh M, Yazdani D, Khalighi-Sigaroodi S, et al. Cytotoxicity and antioxidant activity of 23 plant species of leguminosae family. Iran J Pharm Res 2012;11:295.

12. Federiuk IF, Casey HM, Quinn MJ, Wood MD, Ward KW. Induction of Type-1 diabetes mellitus in laboratory rats by use of alloxan: Route of administration, pitfalls, and insulin treatment. Comp Med 2004;54:252-7.

13. Koster R, Anderson M, De Beer EJ. Acetic acid for analgesic screening. Fed Proc 1959;18:412-8.

14. Turner RA. Analgesics, in Screening Methods in Pharmacology. London, UK: Academic Press; 1965. p. 100-17.

15. Alonso-Castro AJ, Zavala-Sánchez MA, Pérez-Ramos J, SánchezMendoza E, Pérez-Gutiérrez S. Antinociceptive and anti-arthritic effects of kramecyne. Life Sci 2015;121:70-7.

16. Meyer BN, Ferrigni NR, Putnam JE, Jacobsen LB, Nichols DJ, McLaughlin JL. Brine shrimp: A convenient general bioassay for active plant constituents. Planta Med 1982;45:31-4.

17. Deshpande AD, Harris-Hayes M, Schootman M. Epidemiology of diabetes and diabetes-related complications. Phys Ther 2008;88:1254-64.

18. Hossain AI, Faisal M, Rahman S, Jahan R, Rahmatullah M. A preliminary evaluation of antihyperglycemic and analgesic activity of Alternanthera sessilis aerial parts. BMC Complement Alternat Med 2014; 14:169.

19. Ramachandran A, Snehalatha C, Ma RC. Diabetes in South-East Asia: An update. Diabetes Res Clin Pract 2014;103:231-7.

20. Saquib N, Khanam MA, Saquib J, Anand S, Chertow GM, Barry M, et al. High prevalence of Type 2 diabetes among the urban middle class in Bangladesh. BMC Public Health 2013;13:1032.

21. Anand S, Khanam MA, Saquib J, Saquib N, Ahmed T, Alam DS, et al. High prevalence of chronic kidney disease in a community survey of urban Bangladeshis: A cross-sectional study. Global Health 2014;10:9.

22. Muhammad N, Saeed M, Khan H. Antipyretic, analgesic and antiinflammatory activity of Viola betonicifolia whole plant. BMC Complementary Alternat Med 2012;12:59.

23. Ahmed S, Sultana M, Mohtasheem M, Hasan U, Azhar I. Analgesic and antiemetic activity of Cleome viscosa L. Pak J Bot 2011:43:119-22.

24. McLaughlin JL, Chang CJ, Smith DL. Simple Bench-top Bioassays (Brine Shrimp and Potato Discs) for the Discovery of Plant Antitumor Compounds: Review of Recent Progress. United States: In ACS Symposium Series; 1993. 